\title{
Knowledge, attitude and practice of pharmacovigilance among medical students
}

\author{
Darshan Kharadi ${ }^{1}$, Chintan M. Doshi ${ }^{2 *}$
}

${ }^{1}$ Department of Pharmacology, Geetanjali Medical College, Udaipur, Rajasthan, India
${ }^{2}$ Department of Pharmacology, Pacific institute of Medical Sciences, Udaipur, Rajasthan, India

Received: 19 December 2020

Revised: 30 December 2020

Accepted: 04 January 2021

\section{*Correspondence:}

Dr. Chintan M. Doshi,

Email: doshichintan2@gmail.com

Copyright: (c) the author(s), publisher and licensee Medip Academy. This is an open-access article distributed under the terms of the Creative Commons Attribution Non-Commercial License, which permits unrestricted non-commercial use, distribution, and reproduction in any medium, provided the original work is properly cited.

\begin{abstract}
Background: Spontaneous reporting of adverse drug reaction (ADR) is main part of pharmacovigilance. This study was done to assess knowledge, attitude and practice (KAP) of pharmacovigilance among 2nd year medical students. Methods: This was a questionnaire based cross sectional study. The study participants were 2nd year MBBS students at pacific institute of medical sciences. Total number of questions given was 20 . The data was analyzed by MS excel. Results: Total 100 students were given 20 questions. Among 20 questions, 10 were based on knowledge, 4 were based on attitude and 5 were based on practice. One question was asked to determine the reasons for underreporting. $95 \%$ students gave correct definition of pharmacovigilance. 96\% students were having knowledge about existing National pharmacovigilance programme of India. 97\% gave correct answer of side effect occurring during pregnancy as teratogenicity. $99 \%$ said that reporting ADR is necessary.

Conclusions: In our study most of the students gave correct answers of knowledge-based questions. So, knowledge of pharmacovigilance is gradually improving among medical students.
\end{abstract}

Keywords: Pharmacovigilance, ADR, Knowledge, Attitude, Practice

\section{INTRODUCTION}

ADR is defined as "a response to a drug that is noxious and unintended, and which occurs at doses normally used in man for prophylaxis, diagnosis or therapy of disease or for the modification of physiological function". ${ }^{1}$ Adverse effects are not rare; an incidence of $10-25 \%$ has been documented in different clinical settings. 2 Adverse drug effects are divided into: 1. predictable (type A or augmented) reactions, 2. unpredictable (type B or bizarre) reactions. ${ }^{2}$ Pharmacovigilance is defined by WHO as "the science and activities relating to the detection, understanding, and prevention of adverse effects or any other drug related problems". ${ }^{3}$ Their role in strengthening the Pharmacovigilance program by reporting ADRs that would help increase patient safety cannot be overemphasized. Underreporting of ADRs is a common problem in the pharmacovigilance program. ${ }^{4}$ Findings from various studies have revealed that ADR reporting by healthcare providers is linked to their knowledge, attitude, and practice (KAP) about pharmacovigilance. ${ }^{5}$ Swedish study estimated that $3.1 \%$ of deaths in the general population were attributed to ADRs. ${ }^{6}$

\section{METHODS}

Total number of students

The total number of students in the study was 100 


\section{Setting}

This study was conducted at Pacific Institute of Medical sciences, Udaipur. The Duration of study was 2 months from November 2019 to December 2019.

\section{Study design}

This study was a cross-sectional questionnaire study. The study participants were 2 nd year MBBS students. Total 20 questions were given to the students and they were given one day to fill the answers in the questionnaire.

Among 20 questions, 10 were based on knowledge, 4 were based on attitude and 5 were based on practice. One question was asked to determine the reasons for underreporting. These
Questions were designed based on earlier studies for assessing KAP of ADR reporting. ${ }^{7-10}$

\section{RESULTS}

\section{Knowledge}

95\% students gave correct definition of pharmacovigilance. $46 \%$ students were aware that the most important purpose of pharmacovigilance is to identify safety of the drug. $96 \%$ students were having knowledge about existing National pharmacovigilance programme of India. Only $21 \%$ were aware about regulatory body responsible for monitoring ADRs in India, i.e. central drugs standard control organization (CDSCO). $97 \%$ gave correct answer of side effect occurring during pregnancy as teratogenicity (Table 1 and Figure 1).

Table 1: Knowledge based questions.

\begin{tabular}{|c|c|c|}
\hline Questions & Correct $(\%)$ & Incorrect $(\%)$ \\
\hline Define Pharmacovigilance. & 95 & 5 \\
\hline The most important purpose of Pharmacovigilance is. & 46 & 54 \\
\hline The health care professionals for reporting ADR in hospital are. & 50 & 50 \\
\hline Do you know about existence of Pharmacovigilance program of India? & 96 & 4 \\
\hline In India which regulatory body is responsible for monitoring ADRs? & 21 & 79 \\
\hline Where is international center of Pharmacovigilance located? & 95 & 5 \\
\hline Side effect occurring during pregnancy is called. & 97 & 3 \\
\hline Rare ADR can be identified in which phase of Clinical Trial. & 26 & 74 \\
\hline Where is National Pharmacovigilance center in India? & 89 & 11 \\
\hline Is there any Pharmacovigilance Committee in your Institute? & 99 & 1 \\
\hline
\end{tabular}

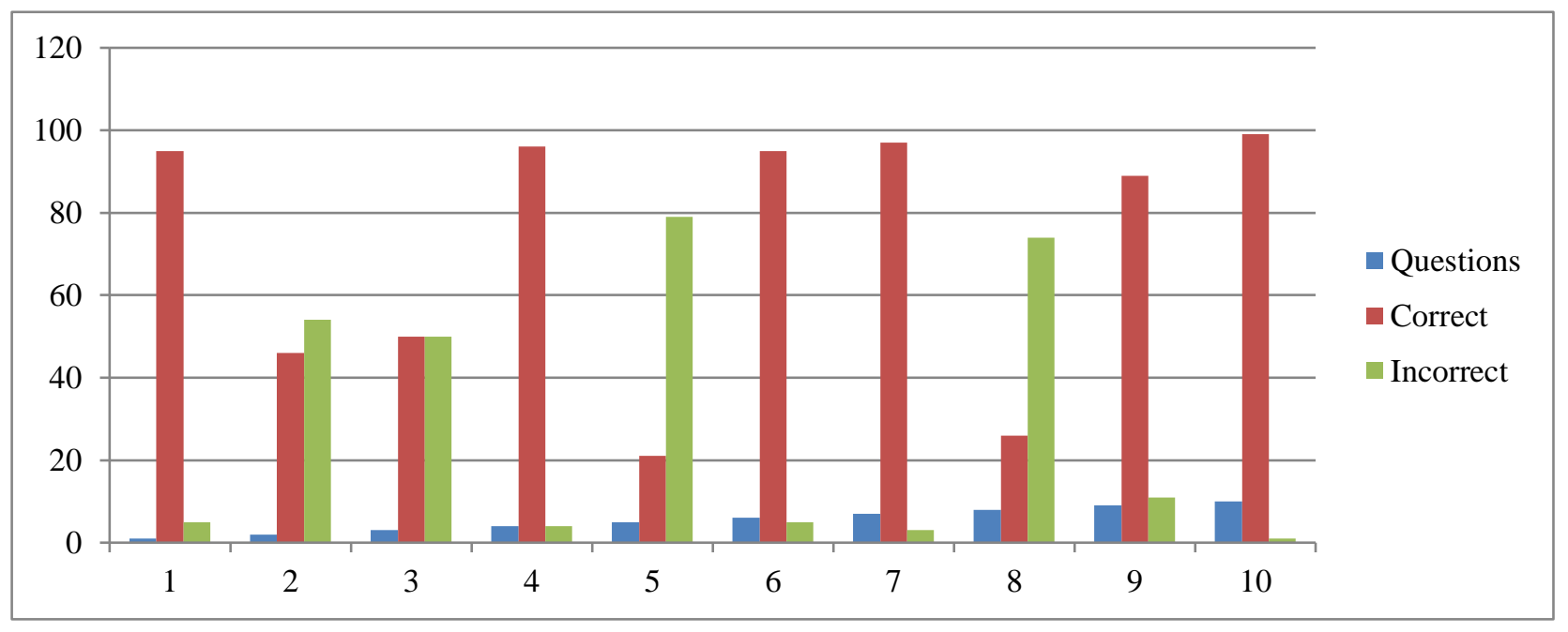

Figure 1: The percentage of responses of knowledge-based questions.

\section{Attitude}

Total $47 \%$ students said that reporting ADR is professional obligation for them. $99 \%$ said that reporting ADR is necessary. $96 \%$ said that Pharmacovigilance should be taught in detail to healthcare professionals. Only $36 \%$ students were agreeing about having Pharmacovigilance center in every hospital (Table 2 and Figure 2).

\section{Practice}

Among students, $41 \%$ have read article on prevention of ADR. $26 \%$ have experienced ADR in patients during their clinical posting. $21 \%$ reported ADR to Pharmacovigilance center. 99\% have seen ADR form. 96\% have been trained on how to report ADR (Table 3 and Figure 3). 
Table 2: Attitude based questions.

\begin{tabular}{lll|}
\hline Questions & Correct (\%) & Incorrect $(\%)$ \\
\hline $\begin{array}{l}\text { Do you think ADR reporting is professional obligation for you? } \\
\text { Do you think reporting of ADR is necessary? }\end{array}$ & 45 & 55 \\
\hline $\begin{array}{l}\text { Do you think Pharmacovigilance should be taught in detail to healthcare } \\
\text { professionals? }\end{array}$ & 96 & 4 \\
$\begin{array}{l}\text { What is your opinion about establishing ADR monitoring center in every } \\
\text { hospital? }\end{array}$ & 36 & 64 \\
\hline
\end{tabular}

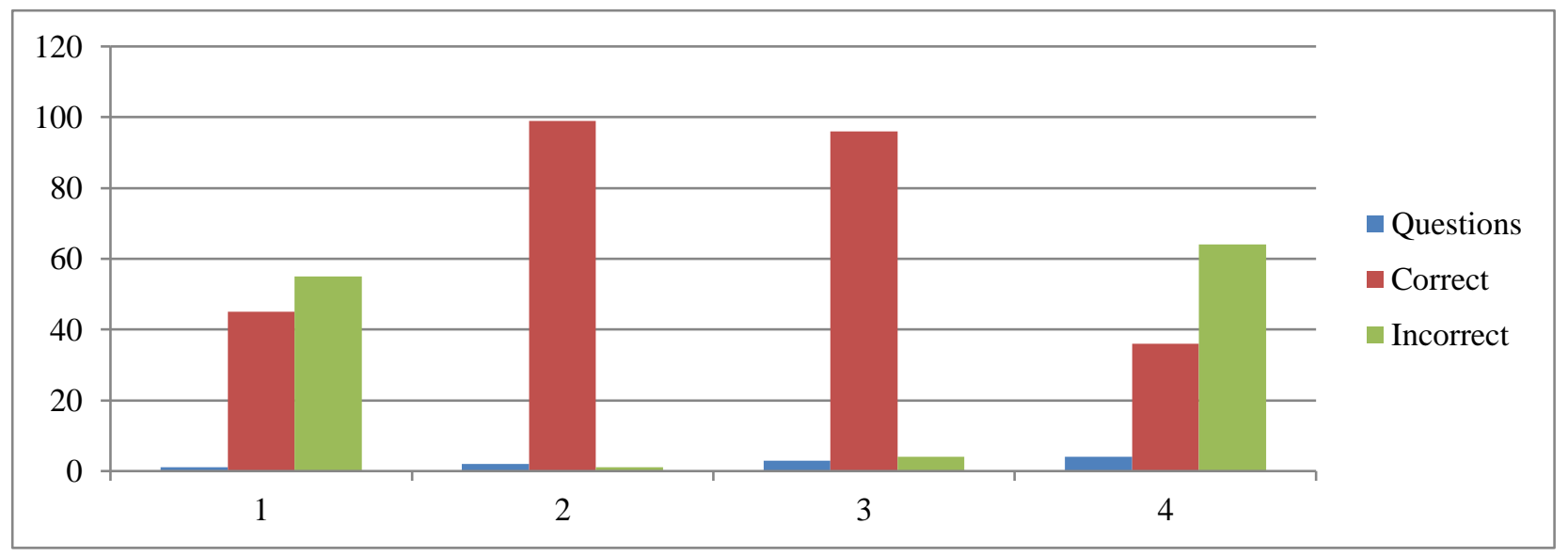

Figure 2: The percentage of responses of Attitude based questions.

Table 3: Practice based questions.

\begin{tabular}{|c|c|c|}
\hline Questions & Yes $(\%)$ & No $(\%)$ \\
\hline Have you read article on prevention of ADR? & 41 & 59 \\
\hline Have you ever experienced ADR in patients during your clinical posting? & 26 & 74 \\
\hline Have you ever reported ADR to Pharmacovigilance center? & 21 & 79 \\
\hline Have you ever seen ADR form? & 99 & 1 \\
\hline Have you ever been trained on how to report ADR? & 96 & 4 \\
\hline
\end{tabular}

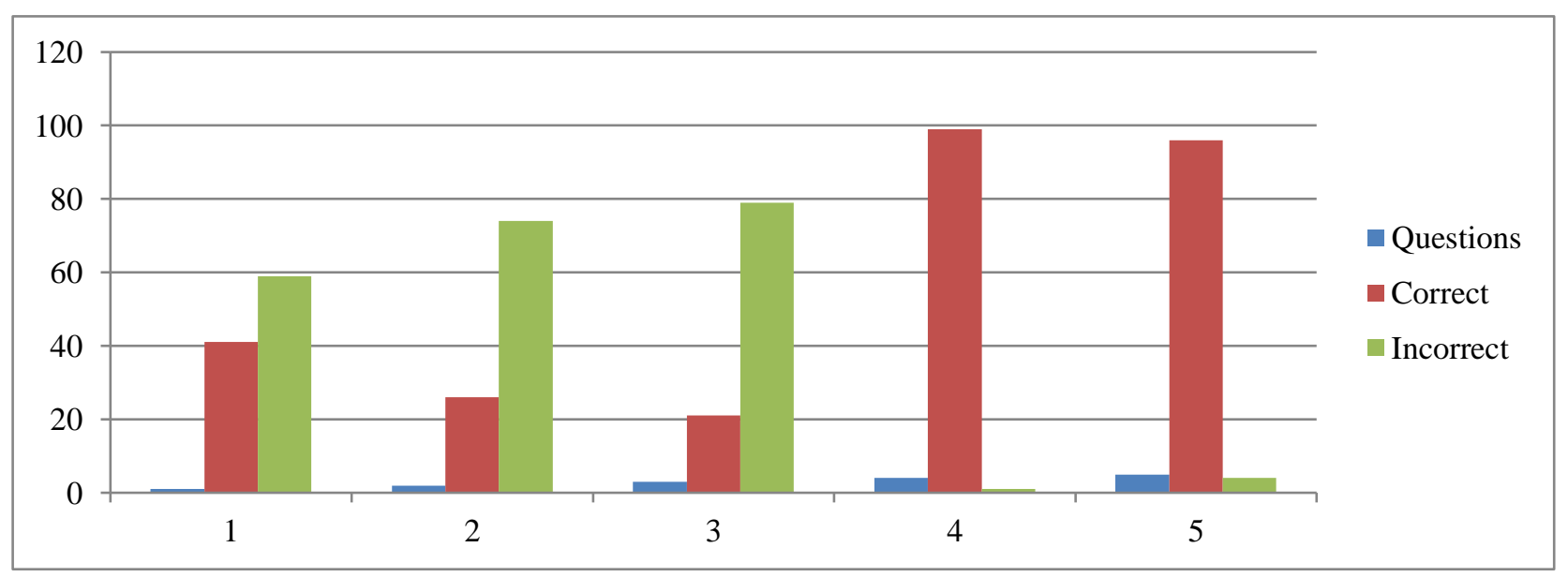

Figure 3: The percentage of responses practice based questions.

\section{DISCUSSION}

Table 4 shows comparison of knowledge and attitudebased questions with different studies. In our study, 95\% students gave correct definition of pharmacovigilance. In a study conducted by Gupta et al this number was $62.5 \% .^{10}$ In our study, $99 \%$ students said that reporting of ADR is necessary. This was comparable by the study conducted by Gupta et al where correct answer was $97 \%$. In our study, 96\% students responded that Pharmacovigilance should be 
taught in detail to healthcare professionals. Similar response was obtained in the study conducted by Gupta et al, where the number was $92.1 \%$. In our study, $89 \%$ gave correct location of pharmacovigilance center in India. In a study conducted by Meher et al only 34\% gave correct answer about location of Pharmacovigilance center. Table 5 shows comparison of practice-based questions with different studies. ${ }^{11,12}$

Table 4: Comparison with results of other studies: knowledge and attitude-based questions. ${ }^{10-12}$

\begin{tabular}{|c|c|c|c|c|}
\hline Questions & $\begin{array}{l}\text { Our study } \\
(\%)\end{array}$ & $\begin{array}{l}\text { Gupta et al }{ }^{10} \\
(\%)\end{array}$ & $\begin{array}{l}\text { Meher et al }{ }^{12} \\
(\%)\end{array}$ & $\begin{array}{l}\text { Pimpalkhute } \\
\text { et } \text { al }^{11}(\%)\end{array}$ \\
\hline Define pharmacovigilance & 95 & 62.4 & 41 & 67.85 \\
\hline $\begin{array}{l}\text { Where is national pharmacovigilance center in } \\
\text { India? }\end{array}$ & 89 & - & 34 & - \\
\hline $\begin{array}{l}\text { Do you know about existence of } \\
\text { pharmacovigilance program of India? }\end{array}$ & 96 & 75.2 & - & 38.4 \\
\hline $\begin{array}{l}\text { The healthcare professionals for reporting ADR } \\
\text { in hospital are. }\end{array}$ & 50 & - & 40 & - \\
\hline $\begin{array}{l}\text { Do you think ADR reporting is professional } \\
\text { obligation for you? }\end{array}$ & 45 & 69.3 & 23 & 35.2 \\
\hline Do you think reporting of ADR is necessary? & 99 & 97 & 59 & - \\
\hline $\begin{array}{l}\text { Do you think Pharmacovigilance should be } \\
\text { taught in detail to healthcare professionals? }\end{array}$ & 96 & 92.1 & - & - \\
\hline
\end{tabular}

Table 5: Comparison with results of other studies: practice-based questions. ${ }^{10,13,14}$

\begin{tabular}{|c|c|c|c|c|}
\hline Questions & $\begin{array}{l}\text { Our study } \\
(\%)\end{array}$ & $\begin{array}{l}\text { Gupta et } a^{10} \\
(\%)\end{array}$ & $\begin{array}{l}\text { Muraraiah et } \\
\mathrm{al}^{13}(\%)\end{array}$ & $\begin{array}{l}\text { Desai et al } \\
(\%)\end{array}$ \\
\hline $\begin{array}{l}\text { Have you ever experienced ADR in patients } \\
\text { during your clinical posting? }\end{array}$ & 26 & 64.4 & 85 & 60 \\
\hline $\begin{array}{l}\text { Have you ever reported ADR to } \\
\text { Pharmacovigilance center? }\end{array}$ & 21 & 22.8 & 15 & 12.4 \\
\hline $\begin{array}{l}\text { Have you ever been trained on how to report } \\
\text { ADR? }\end{array}$ & 96 & 53.5 & - & - \\
\hline
\end{tabular}

Our study has several limitations including comprehensive and appropriate questionnaire adapted to Indian scenario, cross-sectional small sample size without randomization.

\section{CONCLUSION}

In our study most of the students gave correct answer of knowledge-based questions. So, knowledge of pharmacovigilance is gradually improving. The study will bring awareness among students towards Pharmacovigilance and help them in monitoring adverse drug effects.

Funding: No funding sources

Conflict of interest: None declared

Ethical approval: The study was approved by the Institutional Ethics Committee

\section{REFERENCES}

1. International drug monitoring: The role of national centers. Report of a WHO meeting. World Health Organ Tech Rep Ser. 1972;498:1-25.

2. Adverse drug effects In:Tripathi KD, Essentials of Medical Pharmacology: 8th Edition.
3. The Importance of Pharmacovigilance. Safety Monitoring of Medicinal Products. World Health Organization Collaborating Centre for International Drug Monitoring. Geneva: World Health Organization; 2002.

4. Isfahani ME, Mousavi S, Rakhshan A, Assarian M, Kuti L, Eslami K. Adverse drug reactions: attitude and practice of pharmacy students. J Pharm Care. 2013;1:145-8.

5. Rishi RK, Patel RK, Bhandari A. Opinion of physicians towards adverse drug reactions reporting results of pilot study. J Community Nutr Heal. 2012;1:25-9.

6. Wester K, Jönsson AK, Spigset O, Druid H, Hägg S. Incidence of fatal adverse drug reactions: a population based study. Br J Clin Pharmacol. 2008;65:573-9.

7. Upadhyaya P, Seth V, Moghe VV, Sharma M, Ahmed $\mathrm{M}$. Knowledge of adverse drug reaction reporting in first year postgraduate doctors in a medical college. Ther Clin Risk Manage. 2012;8:307-12.

8. Remesh A. Identifying the reasons for under reporting of ADR: A cross sectional survey. Res J Pharm Biol Chem Sci. 2012;3:1379-86.

9. Khan SA, Goyal C, Chandel N, Rafi M. Knowledge, attitude and practice of doctors to adverse drug reaction reporting in a teaching hospital in India: An 
observational study. J Nat Sci Biol Med. 2013;4:1916.

10. Gupta SK, Nayak SP. A questionnaire study on the knowledge, attitude, and the practice of pharmacovigilance among the healthcare professionals in a teaching hospital in South India:An observational study.J Per Cli Research 2015;6(1):4552.

11. Meher BR, A questionnaire based study to assess knowledge, attitude and practice of pharmacovigilance among undergraduate medical students in a Tertiary Care Teaching Hospital of South India. K Per Cli Res. 2015;6(4):217-21.

12. Pimpalkhute SA, Jaiswal KM, Sontakke SD, Bajait CS, Gaikwad A. Evaluation of awareness about pharmacovigilance and adverse drug reaction monitoring in resident doctors of a tertiary care teaching hospital. Indian J Med Sci. 2012;66:55-61.
13. Muraraiah S, Rajarathna K, Sreedhar D, Basavalingu D, Jayanthi CR. A questionnaire study to assess the knowledge, attitude and practice of Pharmacovigilance in a paediatric tertiary care centre. J Chem Pharm Res. 2011;3:416-22.

14. Desai CK, Iyer G, Panchal J, Shah S, Dikshit RK. An evaluation of knowledge, attitude, and practice of adverse drug reaction reporting among prescribers at a tertiary care hospital. Perspect Clin Res. 2011;2:12.

Cite this article as: Kharadi D, Doshi CM.

Knowledge, attitude and practice of pharmacovigilance among medical students. Int $\mathbf{J}$ Basic Clin Pharmacol 2021;10:148-52. 